\title{
The Efficacy of Prebiotic ( $\beta$-Glucan) as a Feed Additive against Toxicity of Aflatoxin B1 in Common Carp, Cyprinus Carpio L.
}

Jamal K Al-Faragi*

Department of Pathology, College of Veterinary Medicine, University of Baghdad, Iraq

\begin{abstract}
This study was undertaken to investigate the adverse effects of aflatoxin B1 (AFB1) on common carp (Cyprinus carpio L) and detoxifying these drastic effects by using prebiotics ( $\beta$-glucan). A total of six treatments were used, including a control diet (G1) that had different combinations of AFB1 and/or $1 \% \beta$-glucan. This included a diet with only

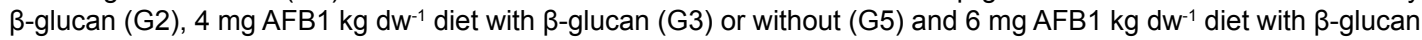
(G4) or without (G6). These diets were offered 6 days a week at $3 \%$ daily of actual biomass in fiberglass aquaria in duplicate (2 aquaria treatment ${ }^{-1}$ ) for 60 days. Several endpoints at different levels of biological organisations were evaluated. These included DNA damage (using comet assay), haematological parameters, histopathological changes of the liver and kidney were also examined and growth performance. Results revealed significantly increase $(P<0.05)$ of DNA damage in AFB1 groups ( $G 5$ and $G 6)$ compared to AFB1 plus $\beta$-glucan groups (G3 and G4). The haematological parameters showed significant differences between AFB1 groups (G5 and G6) and AFB1 plus $\beta$-glucan groups (G3 and G4). Histopathological changes revealed damage to liver and kidney tissues in AFB1 groups. Different levels of AFB1 significantly $(P<0.05)$ affect the final average of fish weight in $\mathrm{G} 5$ and $\mathrm{G} 6$ compared to G3 and G4. Interestingly specific growth rate (\%) of fish was lowered in AFB1 groups (G5 and G6) compared to AFB1 plus 1\% $\beta$-glucan groups (G3 and G4). In conclusion, $\beta$-glucan, found to be a successful agent protected against the genotoxicity induced by AFB1 and effectively alleviate lesions of AFB1. Therefore, obtained results recommended adding $1 \% \beta$-glucan as fish feed additives.
\end{abstract}

Keywords: AFB1; Common carp; Prebiotic; $\beta$-glucan; Histopathology

\section{Introduction}

World aquaculture has grown at an impressive rate over the past years. The model plans that the Aquacultures share in global supply will likely continue to expand to the point where capture fisheries and aquaculture will be contributing equal amounts by 2030 [1]. However, intensive fish farming is associated with risk for the incidence and spread of infectious diseases (bacterial, fungal, viral or parasite infections), decrease of water quality, increase of contamination, and decrease of food quality which can affect the fish health [2].

Aflatoxicosis is a major problem related to aquaculture that leads to economic losses and health complications in fish [3,4]. Aflatoxins are potent toxic, carcinogenic, mutagenic and immunosuppressive agents, produced as secondary metabolites of some strains of the molds mainly Aspergillus flavus, A. parasiticus and A. nominus that grow on food and feed crops [5]. Aflatoxin B1 (AFB1) is the most frequent, potent and toxic metabolite in humans, animals and aquatic organisms [6]. Susceptibility to AFB1 varies according to specific aquatic species. Rainbow trout are the most sensitive fish to the presence of aflatoxin in their diets, with as little as $0.4 \mathrm{ppb}$ ( $\mu \mathrm{g} \mathrm{kg}{ }^{-1}$ of diet) dietary aflatoxin producing heptocellular carcinoma (HCC) in 14 percent of trout over a period of 15 months [7]. Other species such as channel catfish (Ictalurus punctatus), coho salmon (Oncorhynchus kisutch) and zebra fish (Danio rerio) are less sensitive [8-10]. AFs are known as a hepatocarcinogen in various animal species, birds, and rodents [11]. It is also a suspect human carcinogen and has been shown to play a role in human hepatocarcinoma [12]. In parallel with effects in humans the effects in fish also include growth or weight reduction, haematological changes (including anaemia), impaired immunity and DNA damage as well as liver cancer (hepatoma), and even death $[3,4]$. Chronic aflatoxicosis induced significant gross changes and partial damage in the liver of Nile tilapia [3]. Jantrorotai [13] mentioned that, cat fish intraperitoneally injected with aflatoxins showed necrosis of the haemopiotic and renal tissues. Numerous methods have been used in an attempt to control the bioavailability of toxin producing fungi. One of the most practical approaches is the use of adsorbing or binding agents that specifically bind mycotoxins in contaminated feed. However, some adsorbents have been criticized for their negative impact like impair nutrient utilization and mineral absorption $[14,15]$. From a scientific point of view, the use of probiotics and prebiotics has been suggested to become an alternative method and promising area for the prevention and control of fish diseases in aquaculture [16-18]. The use of probiotics, in animal and human nutrition, is well documented [19] and recently, has been gain broad acceptance to aquaculture [20]. Moreover, many researchers have demonstrated that probiotics can enhance the disease resistance of shrimp/fish by suppressing the pathogens, immunostimulant or improving water quality $[16,18,20]$. Evidence of the beneficial effects of probiotics gave birth to the concept of prebiotics. A range of different substances that act as immunostimulants but few are suitable for aquaculture. Among these substances is $\beta$-glucans, which are classified as complex low molecular weight oligosaccharides and generally cannot be digested by the fish but are metabolized by specific microorganisms which prove to be helpful for growth and health of the host [21]. Different types of $\beta$-glucans have been used to increase resistance of fish and crustaceans against bacterial, fungal and viral infections [22-24]. In the light of

*Corresponding author: Jamal K Al-Faragi, Department of Pathology, College of Veterinary Medicine, University of Baghdad, Iraq, Tel: 1510663 7000; E-mail: jamalkhalaf58@yahoo.co.uk

Received March 21, 2014; Accepted May 28, 2014; Published June 18, 2014

Citation: Al-Faragi JK (2014) The Efficacy of Prebiotic ( $\beta$-Glucan) as a Feed Additive against Toxicity of Aflatoxin B1 in Common Carp, Cyprinus Carpio L. J Aquac Res Development 5: 240 doi:10.4172/2155-9546.1000240

Copyright: (c) 2014 Al-Faragi JK, et al. This is an open-access article distributed under the terms of the Creative Commons Attribution License, which permits unrestricted use, distribution, and reproduction in any medium, provided the original author and source are credited. 
above information, There are only limited studies regarding the effect of dietary $\beta$-glucans against toxic effects of AFB1 [23]. Therefore, this study aimed to investigate the adverse effects of AFB1 and also to evaluate the efficacy of $\beta$-glucan against AFB1-induced toxicity in $C$. carpio on different parameters. These parameters will be evaluated at different levels of biological organisation and will include damage at the DNA, haematological parameters, histopathological changes in the major organs (liver and kidney) and growth performance.

\section{Materials and Methods}

\section{Chemicals}

AFB1 was purchased from Sigma-Aldrich Ltd., (Poole and Dorset, UK). $\beta$-glucan was purchased from Hebei Kexing Pharmaceutical Ltd., China.

\section{Diet preparation}

A total of six dietary treatments were formulated, including a control diet (G1) that had different combinations of AFB1 and/or 1\% $\beta$-glucan. This included a diet with only $\beta$-glucan (G2), 4 mg AFB1 kg

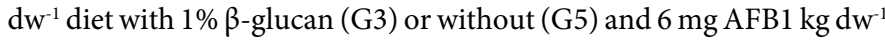
diet with $1 \% \beta$-glucan (G4) or without (G6). The diets were formulated using the same basal ingredients (Table 1) for the control diet except that amount of corn starch was omitted to compensate for the mass of AFB1 (4 and $\left.6 \mathrm{mg} \mathrm{kg} \mathrm{dw}^{-1}\right)$ and $1 \% \beta$-glucan $\left(10 \mathrm{~g} \mathrm{~kg} \mathrm{dw}^{-1}\right)$. Dietary ingredients were mixed in a Hobart food mixer (Model no: HL140010STDA; Hobart Food Equipment, Australia) with warm water until a soft slightly moist consistency was achieved. This was then cold-press extruded (Model P6; La Monferrina, Italy) to produce a $4 \mathrm{~mm}$ pellet. The preparation of aflatoxin-contaminated diets was done every week to avoid loss of the efficacy of the toxic compound due to aging.

\section{Experimental fish and diets}

C. carpio L., (Weighing $45 \mathrm{~g}, \mathrm{n}=250$ ) were obtained from a local fish farm (Babyle Fish Farm, Iraq) and transported to the aquarium facilities. After 2 weeks acclimation and on-growing, 120 fish (average weight $54 \pm 0.23 \mathrm{~g}$ ) were randomly distributed into $12 \times 80$ L fiberglass tanks (10 fish $\left.\operatorname{tank}^{-1}\right)$. Each treatment was conducted in duplicate (two tanks treatment ${ }^{-1}$ ). Fish within different treatment groups were fed three times daily at a rate of $3 \%$ of average body mass for 60 days according to their respective treatment as fellows: Group 1 (G1), fed

\begin{tabular}{|c|c|}
\hline Ingredient & g kg dw $^{\mathbf{1}}$ \\
\hline Corn starch $^{1}$ & 390.00 \\
\hline Fish meal $^{2}$ & 300.00 \\
\hline Lysamine pea protein $^{3}$ & 160.00 \\
\hline Glutalys $^{3}$ & 60.00 \\
\hline Sunflower oil & \\
\hline Fish oil $^{5}$ & 30.00 \\
\hline Vitamin mineral Premix $^{6}$ & 30.00 \\
\hline Molasses & 20.00 \\
\hline
\end{tabular}

Table 1: Dietary ingredients $\mathrm{g} \mathrm{kg} \mathrm{dw}^{-1}$

'Sigma-Aldrich Ltd, UK.

${ }^{2}$ Herring meal LT92-United Fish Products Ltd., Aberdeen, UK.

${ }^{3}$ Roquette Frêres, France.

${ }^{4}$ United Fish Products Ltd., Aberdeen, UK.

${ }^{5}$ Epanoil, Sevenseas, UK

${ }^{6}$ Premier nutrition vitamin/mineral premix: Hebei Kexing Pharmaceutical Co., Ltd, China.

$121 \mathrm{~g} \mathrm{~kg}^{-1}$ calcium, Vit A $1.0 \mu \mathrm{g} \mathrm{kg}^{-1}$, Vit D3 $0.1 \mu \mathrm{g} \mathrm{kg}^{-1}$, Vit E (as alpha tocophero acetate) $7.0 \mathrm{~g} \mathrm{~kg}^{-1}$, Cu (as cupric sulphate) $250 \mathrm{mg} \mathrm{kg}^{-1}$, Magnesium $15.6 \mathrm{~g} \mathrm{~kg}^{-1}$, Phosphorous $5.2 \mathrm{~g} \mathrm{~kg}^{-1}$. control diet (no added AFB1 and $\beta$-glucan); Group 2 (G2), fed basal diet supplemented with $1 \% \beta$-glucan; Group 3 (G3), fish fed AFB1 contaminated diet containing $4 \mathrm{mg} \mathrm{kg} \mathrm{dw}{ }^{-1}$ plus $1 \% \beta$-glucan; Group 4 (G4), fish fed AFB1 contaminated diet containing $6 \mathrm{mg} \mathrm{kg} \mathrm{dw}^{-1}$ plus $1 \%$ $\beta$-glucan; Group 5 (G5), fish fed AFB1 contaminated diet containing $4 \mathrm{mg} \mathrm{kg} \mathrm{dw}{ }^{-1}$; Group 6 (G6), fish groups fed AFB1 contaminated diet containing $6 \mathrm{mg} \mathrm{kg} \mathrm{dw}^{-1}$. Each group was placed in a fully prepared aquarium containing dechlorinated tap water, the average of water temperature was $20 \pm 3.7^{\circ} \mathrm{C}$, dissolved oxygen was in the range 7-8.6 and the $\mathrm{pH}$ was in the range 7.17-8.19 using YSI D.O. meter Model 55 and pen-type HANNA. Through experiments/trials, fish were reweighed every week and within this period feed input was adjusted daily based on a predicted weight/mass. Daily feed was corrected on a weekly basis following batch weighing after a $24 \mathrm{~h}$ starvation period.

\section{Biological sampling and analysis}

At the end of the exposure period (i.e. $60 \mathrm{~d}$ ), fish were not fed the day before the sampling in order to empty the gut before dissection. Three fish per tank $(n=6)$ were netted randomly and quickly anaesthetised in a buffered solution of clove oil (eugenol; $25-50 \mathrm{mg} \mathrm{L}^{-1}$ water for 10 min). Fresh blood samples were immediately obtained from the caudal vein for analysis by single cell electrophoresis (Comet assay) and for the determination percentage of haematocrit, haemoglobin $(\mathrm{Hb})$ concentration, 'leucocytes or white blood cells (WBCs) and red blood cells (RBCs) counts. All haematological parameters were measured according to standard methods [25].

\section{Single cell gel electrophoresis (Comet assay)}

Comet assay was performed to determine DNA damage as described by [25]. Briefly, frosted end microscope slides were coated with $1.5 \%$ normal melting point (NMP) agarose and allowed to air dry. Erythrocytes were pelleted in a microcentrifuge tubes and suspended in $170 \mathrm{IL}$ molten $0.75 \%$ low melting point (LMP) agarose. This was then applied as two drops (85 IL) to the precoated slides. Cover glasses were placed over each drop and gels were allowed to set at $4^{\circ} \mathrm{C}$ for $1 \mathrm{~h}$. When gels had solidified, cover glasses were gently removed and slides were immersed in cold $\left(4^{\circ} \mathrm{C}\right)$ lysing solution $(\mathrm{pH} 10,1 \mathrm{~h})$. Following cell lysis, the slides were placed in electrophoresis unit containing freshly prepared electrophoresis buffer $(\mathrm{pH}<13)$. The DNA was allowed to unwind for $15 \mathrm{~min}$ before electrophoresis was performed $(25 \mathrm{~V}, 300 \mathrm{~mA}, 20 \mathrm{~min})$. After that, the slides were gently immersed in neutralization buffer ( $\mathrm{pH} 7.4,10 \mathrm{~min}$ ), before a final wash in distilled water. Finally, to visualise comets, ethidium bromide stain (40 IL; $0.2 \%$ ) was applied to each gel. Scoring was conducted using fluorescence microscope (Leica DMR) using Komet 5.0 image analysis software (Kinetic Imaging, Ltd., UK). Comet scores for 100 cells from each slide (50 cells gel ${ }^{-1}$ ). Percentage of tail DNA was chosen as a reliable measure of single-strand DNA breaks/alkali labile sites [26].

\section{Histopathological studies}

Histological assessment of the liver and kidney tissues was conducted at the end of exposure period using light microscopy as described by [27]. Briefly, three fish per tank $(n=6)$ were dissected out, tissue samples were fixed in $10 \%$ neutral buffer formalin, dehydrated in serial grades of ethyl alcohol, cleared by xylol, embedded in paraffin wax. Sections (3-5 $\mu \mathrm{m}$ thick) stained with Haematoxyline and Eosin (H\&E) and then examined microscopically for recording the hisopathological alterations. A quantitative assessment of lesions in histopathological investigation was done through practicable statistics (ANOVA). 


\section{Growth performances measurements}

Growth performance and feed utilisation were assessed by weight gain, specific growth rate (SGR) and feed conversion efficiency (FCE). Calculations were conducted according to [28] using the following formulae: SGR $(\%)=(\mathrm{InFW}-\mathrm{InIW} / \mathrm{T}) \times 100, \quad \mathrm{FCE} \%=(\mathrm{FI} / \mathrm{WG}) \times 100$. Where FW=Final Weight $(\mathrm{g}), \mathrm{IW}=\mathrm{Initial}$ Weight $(\mathrm{g}), \mathrm{T}=$ Duration of Feeding (days), WG=Wet Weight Gain (g), FI=Feed Intake (g).

\section{Statistical analysis}

Statistical analysis was performed using Statgraphics vs 5.1 software (StatSoft, USA). All data were presented as mean \pm standard error (S.E.) and analysed using one way analysis of variance (ANOVA) or Kruskal Wallis test, followed by multiple range tests. $P$ values $<0.05$ were considered significant.

\section{Determination of DNA damage}

In the present study after 60 days of dietary exposure to different concentrations of AFB1 contaminated diets and AFB1 plus $\beta$-glucan, no loss of cell viability was observed in any of the treatments (cell viability in the trypan blue exclusion dye, $>90 \%$ in all cases). DNA damage was relatively low in control (G1) and in prebiotic group (G2) compared to AFB1groups (G5 and G6) and to AFB1 plus $\beta$-glucan groups (G3 and G4). DNA strand breaks (i.e. \%DNA in tail) was increased significantly $(P<0.05)$ in AFB1 contaminated diet groups $(\mathrm{G} 5$ and G6) compared to control (G1), prebiotic groups (G2) and to AFB1 plus $\beta$-glucan groups (G3 and G4). In addition, there was a significant difference $(P<0.05)$ between AFB1 groups (i.e. G6 and G5) (Figure 1). These results indicated that DNA damage depended upon AFB1 concentrations. The present investigation using comet assay revealed the significant increase of DNA damage in AFB1 contaminated groups (G5 and G6) and the modifying responses due to $\beta$-glucan administration in C. carpio. Typically, in this assay the healthy cells (intact cells) are visualized as circular fluorescing spots, while the fragmentation of nuclear DNA into nucleosomal size is visualized as

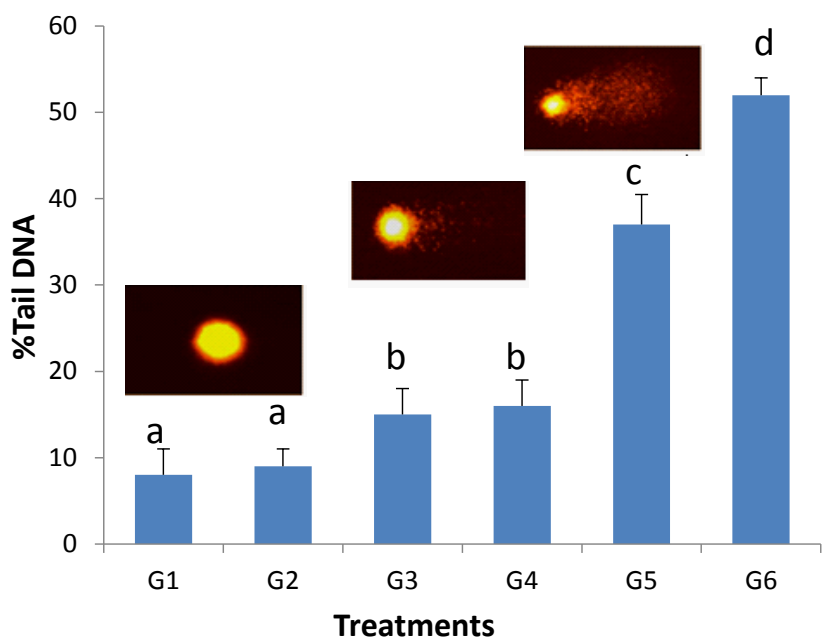

Figure 1: Induction of DNA single strands breaks (represented as percentage tail DNA) in C. carpio erythrocytes following 60 days exposure to different concentrations of AFB1 contaminated diets and to AFB1 plus $\beta$-glucan. Values are mean \pm S.E. alphabetic letters indicate significant difference at $P<0.05$; $\mathrm{n}=6$. G1-(Control diet); G2-(fed diet containing 1\% $\beta$-glucan); G3-(fed diet containing $4 \mathrm{mg} \mathrm{AFB1} \mathrm{kg} \mathrm{dw}^{-1}$ plus $1 \% \beta$-glucan; G4-(fed diet containing $6 \mathrm{mg}$ AFB1 $\mathrm{kg} \mathrm{dw}^{-1}$ plus $1 \%$-glucan); G5-(4 mg AFB1 kg dw$\left.{ }^{-1}\right)$; G6-(6 mg AFB1 kg $\left.d w^{-1}\right)$.

\begin{tabular}{|l|l|l|l|l|}
\hline $\begin{array}{l}\text { Fish } \\
\text { Groups }\end{array}$ & RBC & Hb (g/dl) & PCV\% & $\begin{array}{l}\text { WBC } \\
\left.\text { (cellsx10 }{ }^{3} \boldsymbol{\mu l}\right)\end{array}$ \\
\hline G1 & $03.32 \pm 0.25^{\mathrm{a}}$ & $09.32 \pm 0.26^{\mathrm{a}}$ & $34.54 \pm 1.04^{\mathrm{a}}$ & $13.11 \pm 0.65^{\mathrm{a}}$ \\
\hline G2 & $03.12 \pm 0.20^{\mathrm{a}}$ & $09.44 \pm 0.12^{\mathrm{a}}$ & $34.16 \pm 1.24^{\mathrm{a}}$ & $14.09 \pm 0.09^{\mathrm{a}}$ \\
\hline G3 & $02.70 \pm 0.08^{\mathrm{b}}$ & $13.51 \pm 0.03^{\mathrm{b}}$ & $38.00 \pm 0.80^{\mathrm{b}}$ & $16.05 \pm 0.05^{\mathrm{b}}$ \\
\hline G4 & $02.89 \pm 0.05^{\mathrm{b}}$ & $13.57 \pm 0.06^{\mathrm{b}}$ & $37.00 \pm 0.60^{\mathrm{b}}$ & $16.04 \pm 0.83^{\mathrm{b}}$ \\
\hline G5 & $01.42 \pm 0.30^{\mathrm{c}}$ & $07.57 \pm 0.09^{\mathrm{c}}$ & $30.00 \pm 0.10^{\mathrm{c}}$ & $17.32 \pm 0.93^{\mathrm{c}}$ \\
\hline G6 & $01.34 \pm 0.80^{\mathrm{c}}$ & $06.57 \pm 0.45^{\mathrm{c}}$ & $31.00 \pm 0.30^{\mathrm{c}}$ & $18.11 \pm 0.31^{\mathrm{c}}$ \\
\hline
\end{tabular}

Table 2: Haematological parameters (red blood cells count, haemoglobin concentration, haematocrit and white blood cells count) of. carpio as affected by the dietary treatments for 60 days.

Data are mean \pm S.E. Groups with different alphabetic superscripts within the row indicate significant difference at $P<0.05$; (G1-(Control diet); G2-(fed diet containing $1 \% \beta$-glucan); G3-(fed diet containing 4 mg AFB1 kg dw ${ }^{-1}$ plus $1 \%$-glucan; G4-(fed diet containing $6 \mathrm{mg} \mathrm{AFB} \mathrm{kg} \mathrm{dw}^{-1}$ plus $1 \%$-glucan); G5-(4 mg AFB1 $\left.\mathrm{kg} \mathrm{dw}^{-1}\right)$; G6-(6 mg AFB1 kg dw $\left.{ }^{-1}\right)$.

\begin{tabular}{|c|c|c|c|c|c|}
\hline $\begin{array}{c}\text { Fish } \\
\text { Groups }\end{array}$ & Initial weight & Final weight & SGR (\%) & FCE\% & SR \\
\hline G1 & $55.31 \pm 0.44^{\mathrm{a}}$ & $79.81 \pm 0.01^{\mathrm{a}}$ & $0.59 \pm 0.10^{\mathrm{a}}$ & $9.79 \pm 0.20^{\mathrm{a}}$ & $\mathbf{1 0 0 \%}$ \\
\hline G2 & $54.37 \pm 0.88^{\mathrm{a}}$ & $83.28 \pm 0.01^{\mathrm{a}}$ & $0.71 \pm 0.01^{\mathrm{a}}$ & $8.43 \pm 0.30^{\mathrm{a}}$ & $\mathbf{1 0 0 \%}$ \\
\hline G3 & $55.01 \pm 0.23^{\mathrm{a}}$ & $75.18 \pm 1.11^{\mathrm{a}}$ & $0.52 \pm 0.10^{\mathrm{a}}$ & $11.18 \pm 0.90^{\mathrm{b}}$ & $\mathbf{9 5 \%}$ \\
\hline G4 & $53.57 \pm 0.10^{\mathrm{a}}$ & $73.33 \pm 1.01^{\mathrm{b}}$ & $0.52 \pm 0.20^{\mathrm{a}}$ & $11.13 \pm 0.07^{\mathrm{b}}$ & $\mathbf{9 5 \%}$ \\
\hline G5 & $54.68 \pm 0.44^{\mathrm{a}}$ & $66.23 \pm 2.61^{\mathrm{c}}$ & $0.31 \pm 0.09^{\mathrm{b}}$ & $17.20 \pm 0.50^{\mathrm{c}}$ & $\mathbf{7 5 \%}$ \\
\hline G6 & $54.37 \pm 0.88^{\mathrm{a}}$ & $67.21 \pm 2.50^{\mathrm{c}}$ & $0.35 \pm 0.08^{\mathrm{b}}$ & $15.70 \pm 0.10^{\mathrm{c}}$ & $\mathbf{7 0 \%}$ \\
\hline
\end{tabular}

Table 3: Summary of growth performances (initial weight, final weight, specific growth rate, feed conversion efficiency and survival rate) of $C$. carpio.

Data are mean \pm S.E. Groups with different alphabetic superscripts within the row indicate significant difference at $P<0.05$; (G1-(Control diet); G2-(fed diet containing $1 \% \beta$-glucan); G3-(fed diet containing 4 mg AFB1 $\mathrm{kg} \mathrm{dw}^{-1}$ plus $1 \%$-glucan; G4-(fed diet containing $6 \mathrm{mg} \mathrm{AFB1} \mathrm{kg} \mathrm{dw}^{-1}$ plus $1 \% \beta$-glucan); G5-( $4 \mathrm{mg}$ AFB1 $\left.\mathrm{kg} \mathrm{dw}^{-1}\right)$; G6-(6 mg AFB1 kg dw-1)

the tail. The significant reduction seen in the $\beta$-glucan co-administered groups (G3 and G4) of fish which was confirmed by agarose gel electrophoresis could be attributed to its ability to enhance DNA repair activity. Particularly, prebiotics like $\beta$-glucan are known as antioxidant to scavenge the free radicals and oxidants [29]. The presence of this property in $\beta$-glucan could actively scavenging the reactive oxygen species (ROS) assault on DNA thereby appears to inhibit the formation of AFB $1 \mathrm{~N}^{7}$ Gua and apurinic sites hence explaining the decreased DNA damage in $\beta$-glucan supplemented groups. These results are consistent with pervious findings, which report that the antioxidant supplement, Amrita Bindu, has a potential role in ameliorating the AFB1-induced DNA damage [30,31]. In a study, Madhusudhanan [32] also showed that the salt spice herbal mixture Amrita Bindu is able to prevent the AFB1-induced oxidative damage to lipids and proteins in liver, kidney and brain tissues of Labeo rohita. This trail confirms the respectable efficiency of $\beta$-glucan in preventing the AFB1-induced DNA damage.

\section{Determination of haematological parameters}

The results of haematological indices for the dietary treatments are presented in table 2 . These results revealed significantly decrease $(P<0.05)$ in RBCs count, $\mathrm{Hb}$ concentration, PCV\% in the G5 and G6 treatments and a significant increase in WBCs count compared to control (G1) and to prebiotic group (G2). On the other hand, these parameters were tended to increase in AFB1 plus $\beta$-glucan groups (G3 and G4) compared to AFB1 groups (G5 and G6) values. Also, G3 and G4 treatments showed significant increase $(P<0.05)$ in RBCs count, $\mathrm{Hb}$ concentration, PCV\%, and WBCs count compared to control (G1) and to $\beta$-glucan group (G2). Additionally, there were significant differences between AFB1 groups (i.e. G5 and G6) and AFB1 plus $\beta$-glucan groups (G3 and G4). The results of AFB1 groups (G5 and G6) are similar to 
the findings of $[33,34]$. Similar negative effects of AFB1 contaminated diet on blood parameters of tilapia fish were recorded also by Nguyen [35]. This decrease in hematological parameters may be due to many factors such as inhibition of protein synthesis, decrease of the total iron binding capacity and the hemopoietic cellular defects of AFB1 [36]. Furthermore, the increase in blood indices in AFB1 plus $\beta$-glucan could be attributed to the fact that, the $\beta$-glucan increases the blood parameter values as a result of hemopiotic stimulation or could be due to its constituents that stimulate the immune system. In addition, $\beta$-glucan could overcome the drastic effects of AFB1 on some vital organs as the liver and kidney, acting as hepatotoxic, nephrotoxic and inhibition of DNA, RNA and protein synthesis.

\section{Histopathological studies}

The liver section of control (G1) and diet containing only $1 \%$ $\beta$-glucan (G2) exhibited normal morphological structures with no abnormalities in the hepatocytes. It showed a homogenous cytoplasm around a centrally located spherical nucleus (Figure 2A). Microscopic examination showed histopathological changes in G5 and G6 after 60 days of feeding trail compared to the control (G1) and $1 \%$ $\beta$-glucan group (G2).Hepatocytes in 4 fish (out of 6) lost their normal boundaries. There were severe cellular and vacuolar degeneration accompanied with necrotic changes represented by pyknosis of the nuclei as well as necrosis (Figure 2B-2D) livers of the AFB1 plus $1 \%$ $\beta$-glucan groups (G3 and G4) showed histopathological alterations including cytoplasmic vacuolation and nuclear degeneration but significantly decreased $(P<0.05$; data not shown) compared to AFB1 groups (G5 and G6).

For the kidney, all tubules, glomeruli and other elements of the nephrons appeared normal, in both control and prebiotic groups with no evidence of oedema, necrosis (Figure 3A). AFB1 contaminated diets groups (G5 and G6) exhibited severe histopathological changes. There were hemosiderosis together with melanomacrophage infiltration in tubules, degenerative changes in the form of cytoplasmic vacuolation and acute cellular degeneration of the tubular epithelium and necrosis in the tubular epithelium and endothelial lining (Figure 3B-3D). These changes (i.e., hemosiderosis, melanomacrophage infiltration

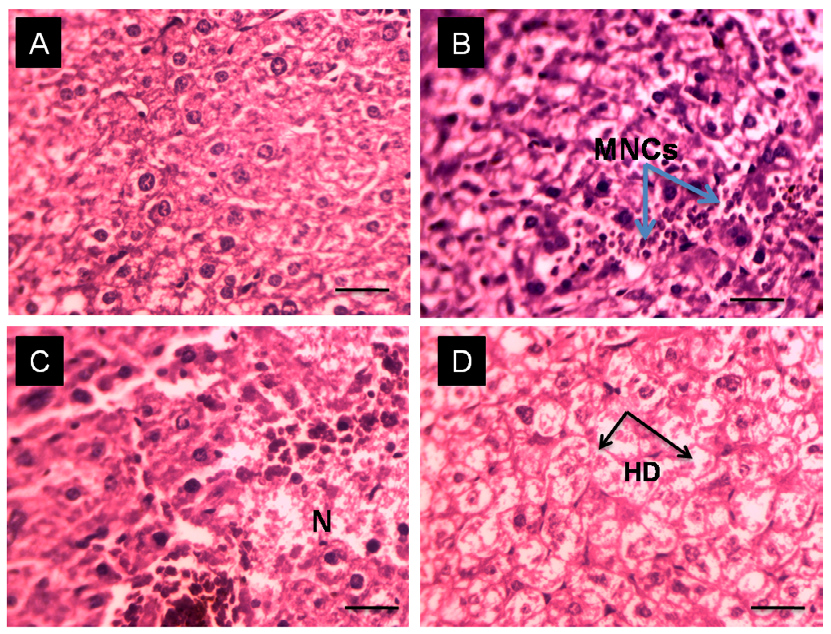

Figure 2: Light micrograph sections showing histological structures through liver of $C$. carpio affected by dietary treatment at $5 \mu \mathrm{m}$ thickness. (A) control liver showing normal histology (B) aflatoxic liver (4 $\left.\mathrm{mg} \mathrm{kg} \mathrm{dw}^{-1}\right)$ showing mononuclear cells (MNCs) infiltration (C\&D) aflatoxic liver (6 mg kg dw' showing necrosis $(\mathrm{N})$ with MNCs infiltration, enlargement of the hepatocytes (black arrows) with hydropic degeneration (HD). Scale bars: $50 \mu \mathrm{m}, \mathrm{H} \& \mathrm{E}$.

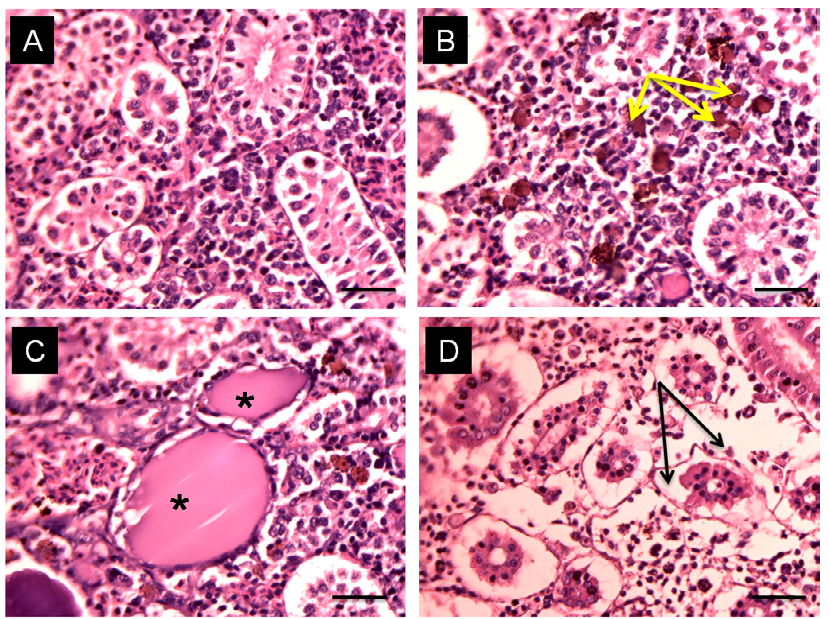

Figure 3: Light micrograph sections showing histological structures through kidney of $C$. carpio affected by dietary treatment at $5 \mu \mathrm{m}$ thickness. (A) control kidney showing normal histology (B) aflatoxic kidney $\left(4 \mathrm{mg} \mathrm{kg} \mathrm{dw}^{-1}\right)$ showing hemosiderosis together with melanomacrophage infiltration (yellow arrows) (C\&D) aflatoxic kidney $\left(6 \mathrm{mg} \mathrm{kg} \mathrm{dw}^{-1}\right)$ showing infiltration of protein substances in tubules $\left(^{*}\right)$, degenerative changes in the form of cytoplasmic vacuolation and acute cellular degeneration of the tubular epithelium and necrosis in the tubular epithelium (black arrows). Scale bars: $50 \mu \mathrm{m}, \mathrm{H} \& \mathrm{E}$.

acute cellular degeneration and necrosis) were significantly decreased $(P<0.05$; data not shown). These changes are in agreement with Boonyaratpalin [3,37]. Also, these results are in line with Caguan [38] who revealed alterations in the liver of Nile tilapia (Oreochromis niloticus L). Joner A [39] described the effect of aflatoxin in the liver as follows: first, aflatoxin is absorbed from the diet in the alimentary canal and is passed to different organs. The principal target organ for aflatoxins is the liver. After the invasion of aflatoxins into the liver, lipids infiltrate hepatocytes and leads to necrosis or liver cell death. The main reason for this is that aflatoxin metabolites react negatively with different cell proteins, which leads to inhibition of carbohydrate and lipid metabolism and protein synthesis. In relation with the decrease in liver function, there is an anemia, and a decrease in essential serum proteins synthesized by the liver. The histopathological changes in kidney were similar to findings obtained by Jantrorotai [13]. Caguan [38] mentioned that, these lesions developed as a result of immunosuppressive effect of aflatoxin.

\section{Growth performance and survival rate}

Data presented in table 3 showed that aflatoxin contaminated diets had negative effects $(\mathrm{P}<0.05)$ on fish growth performance. SGR (\%) of the experimental fish for the control (G1) and prebiotic group (G2) recorded the highest values $(0.59 \%, 0.71 \%$ respectively) followed by G3 and G4 (0.52\%). SGR (\%) was not significantly different in G3 and G4 treatments compared to G1 and G2 treatments. While SGR (\%) for AFB1 contaminated diet revealed that G5 and G6 had the lowest SGR $(0.31 \%$ and $0.35 \%$ respectively) which was significantly different compared to G3 and G4 (0.52\%). This result suggests that the SGR (\%) was significantly reduced by the increase level of AFB1[40]. On the other hand, FCE\% were significantly decreased $(P<0.05)$ in G1, G2, G3 and G4 in comparison with AFB1groups (G5 and G6). Also, FCE\% were significantly different $(P<0.05)$ in AFB1 plus $1 \%$ $\beta$-glucan groups (G3 and G4) in comparison with control (G1) and $\beta$-glucan group (G2). Mean percent survival in the different treatments were significantly different $(\mathrm{P}<0.05)$. Decreasing of survival rate was observed as AFB1contamination in the feed increased. The lowest 
percent survival was obtained in G6 (70\%) and in G5 (75\%) while G3 and G4 treatments gave 95\% survival (i.e., mortality increased as AFB1 level in the feed increased). These results are in line with the findings in Oreochromis aureaus [41], in Oreochromis niloticus [35], in Clarius lazera [42] and in Labeo rohita [43]. The decrease in growth rate in experimental fish could be due to disturbance in metabolic process of lipids, carbohydrates and proteins by aflatoxin that reacts negatively with different cell protein which leads to inhibition of carbohydrate and lipid metabolism and protein synthesis [39]. Robertsen [43] reported that aflatoxin causes loss of appetite. Thus the decrease in average weight gain could also be due to loss of appetite. Survival rate was decreased significantly $(\mathrm{P}<0.05)$ in fish fed AFB1 contaminated diets in comparison with other treatments. These results are in agreement with the findings reported by Salem [33] who mentioned that AFB1contaminated diet at levels of $0.1 \mathrm{mg} \mathrm{kg} \mathrm{dw}^{-1}$ and $0.15 \mathrm{mg}$ $\mathrm{kg} \mathrm{dw}^{-1}$ significantly increased the mortality rate in tilapia. The present findings are also in line with Caguan [38].

\section{Conclusion}

The overall results of this study suggest that $\beta$-glucan could effectively bind the aflatoxins and attenuate its adverse effects. Furthermore, it is demonstrated for the first time that co-administration of an antioxidant inducer, $\beta$-glucan with AFB1 could apparently prevent the AFB1-induced DNA damage, and protected against the genotoxicity induced by AFB1. It could be concluded that adding $1 \% \beta$-glucan to diets of common carp showed positive effects.

\section{Acknowledgment}

This study was funded by the Ministry of Higher Education and Scientific Research/Iraq. I wish to thank all my research assistants for their contribution in the process of organizing the trial, feeding of carp, data collection and investigation the samples.

\section{References}

1. AES. Agriculture and Environmental Services (2013) Fish to 2030 Prospects for Fisheries and Aquaculture. The World Bank Report Number 83177-GLB.

2. Nomoto K (2005) Prevention of Infections by Probiotics. Journal of Bioscience and Bioengineering 100: 583-592.

3. Chaves SMC, Martinez BCA, Osorio MI (1994) Pathological Effects of Feeding Young Oreochromis Niloticus Diet Supplemented with Different Level of Aflatoxin B1. Aquaculture 127: 49-60.

4. Santacroce MP, Conversano MC, Casalino E, Lai O, Zizzadoro C, et al. (2008) Aflatoxins In Aquatic Species: Metabolism, Toxicity and Perspectives. Rev Fish Biol Fish 18: 99-130.

5. Cotty PJ, Jaime-Garcia R (2007) Influences of Climate on Aflatoxin Producing Fungi and Aflatoxin Contamination. Int J Food Microbial 119: 109-115.

6. Kennedy D, Delaney A, Koren G (1998) Mutagens, Carcinogens and Teratogens. In: Goldfrank L (Ed) Goldfrank's Toxicologic Emergencies, $6^{\text {th }}$ Edn. Appleton \& Lange, Stanford 262-273.

7. Horn CW, Boleman LL, Coffman CG, Deton JH, Lawhorn DB (1989) Mycotoxins in Feed and Food Producing Crops College State Texas. Texas Vet Med Diagnostic, The National Dairy Database (1992)

8. Hendricks JD, Bailey GS (1989) Adventitious Toxins. In: Halver JE (Ed) Fish Nutrition, $2^{\text {nd }}$ Edn. Academic Press Inc., New York 605-651.

9. Plakas SM, Loveland PM, Bailey GS, Blazer VS, Wilson GL (1991) Tissue Deposition and Excretion of 14C-Labeled Aflatoxin B1 after Oral Administration in Channel Catfish. Food Chem Toxicol 29: 805-808.

10. Tsai HW (1996) Evaluation of Zebrafish (Brachydanio Rerio) as a Model for Carcinogenesis. Doctoral Dissertation, Oregon State University.

11. Allameh A, Safamehr A, Mirhadi SA, Shivazad M, Razzaghi-Abyaneh M et al. (2005) Evaluation of Biochemical and Production Parameters of Broiler Chicks Fed Ammonia Treated Aflatoxin Contaminated Maize Grains. Anim Feed Sci Technol 122: 289-301.
12. Wang JS, Hang T, Su J, Liang F, Wei Z, et al. (2001) Hepatocellular Carcinoma and Aflatoxin Exposure in Zhuqing Village, Fusui County, Peoples.Cancer Epidemiol Biomark Prev 10: 143-146.

13. Jantrorotai W, Lovell RT (1990) Subchronic Toxicity of Dietary Aflatoxin B1 to Channel Cat Fish. J Aquat Anim Health 2: 248-254.

14. Chestnut AB, Anderson PD, Cochran MA, Fribourg HA, Twinn KD (1992) Effects of Hydrated Sodium Calcium Aluminosilicate on Fescue Toxicosis and Mineral Absorption. J Anim Sci 70: 2838-2846.

15. Kubena LF, Harvey RB, Huff WE, Ellisalde MH, Yersin AG, et al. (1993) Efficacy of a Hydrated Sodium Calcium Aluminosilicate to Reduce The Toxicity of Aflatoxin and Diacetoxyscirpenol. Poult Sci 72: 51-59.

16. Nayak SK (2010) Probiotics and Immunity: A Fish Perspective. Fish Shellfish Immunol 29: 2-14.

17. Ringo E, Olsen RE, Gifstad TO, Dalmo RA, Amlund H, et al. (2010) Prebiotics in Aquaculture: A Review. Aquacult Nutr 16: 117-136.

18. Merrifield D, Harper G, Mustafa S, Carnevali O, Picchietti S, et al. (2011) Effect of Dietary Alginic Acid on Juvenile Tilapia (Oreochromis Niloticus) Intestinal Microbial Balance, Intestinal Histology and Growth Performance. Cell Tis Res 344: $135-146$

19. Rinkinen M, Jalava K, Westermarck E, Salminen S, Ouwehand AC (2003) Interaction Between Probiotic Lactic Acid Bacteria and Canine Enteric Pathogens: A Risk Factor for Intestinal Enterococcus Faecium Colonization. Vet Microbiol 92: 111-119.

20. Wang YB, Li JR, Lin JD (2008) Probiotics in Aquaculture: Challenges and Outlook. Aquaculture 28: 11-14.

21. Manning T, Gibson G (2004) Prebiotics. Best Practice \& Research in Clinical Gastroenterology, 18: 287-298.

22. Paulsen SM, Engstad RE, Robertsen B (2001) Enhanced Lysozyme Production in Atlantic Salmon (Salmo Salar L.) Macrophages Treated with Yeast B-Glucan and Bacterial Lipopolysaccharide. Fish Shellfish Immunol 11: 23-37.

23. Sahoo PK, Mukherjee SC (2001) Effect of Dietary B-1,3 Glucanresponse and Disease Resistance of Healthy and Aflatoxin B1-Induced Immunocompromised Rohu (Labeo Rohita Hamilton). Fish Shellfish Immunol 11: 683-695.

24. Bagni M, Romano N, Finoia MG, Abelli L, Scapigliati G, et al. (2005) Short and Long-Term Effects of a Dietary Yeast B-Glucan (Macrogard) and Alginic Acid (Ergosan) Preparation on Immune Response in Sea Bass (Dicentrarchus Labrax). Fish Shellfish Immunol 18: 311-325.

25. Mustafa SA, Davies SJ, Jha AN (2012) Determination of Hypoxia and Dietary Copper Mediated Sub-Lethal Toxicity in Carp, Cyprinus Carpio, at Different Levels of Biological Organisation. Chemosphere 87: 413-420.

26. Kumaravel T, Jha AN (2006) Reliable Comet Assay Measurements for Detecting DNA Damage Induced by lonising Radiation and Chemicals. Mutat Res 605: 7-16.

27. Myers MS, Johnson LL, Hom T, Collier TK, Stein JE, et al. (1998) Toxicopathic Hepatic Lesions in Subadult English Sole (Pleuronectes Vetuls) From Puget Sound, Washington, USA: Relationships with Other Biomarkers of Contaminant Exposure. Mar Environ Res 45: 47-67.

28. Cech JJ, Mitchell SJ, Wragg TE (1984) Comparative Growth of Juvenile White Sturgeon and Striped Bass: Effects of Temperature and Hypoxia. Estuaries and Coasts 7: 12-18

29. Kyoko Kofuji, Ayumi Aoki, Kazufumi Tsubaki, Masanori Konishi, Takashi Isobe et al. (2012) Antioxidant Activity of $\beta$-Glucan. International Scholarly Research Network 1: 1-5.

30. Meki AR, Abdel-Ghaffar SK, El-Gibaly I (2001) Aflatoxin B1 Induces Apoptosis in Rat Liver. Protective Effect of Melatonin. Neuro Endocrinol Lett 22: 417-426.

31. Madhusudhanan SN, Kavithalakshmi, ERB, Shanmugasundaram, Shanmugasundaram KR (2006) Aflatoxin B1-Induced DNA Damage in Labeo Rohita: Protective Effect of an Antioxidant Supplement, Amrita Bindu. Basic Clinic Pharmacol Toxicol 98: 473-479.

32. Madhusudhanan NSN, Kavithalakshmi K, Shanmugasundaram ERB (2004) Oxidative Damage to Lipids and Proteins Induced by Aflatoxin B1 in Fish (Labeo Rohita)-Protective Role of Amrita Bindu. Env Toxicol Pharmacol 17 73-77. 
Citation: Al-Faragi JK (2014) The Efficacy of Prebiotic ( $\beta$-Glucan) as a Feed Additive against Toxicity of Aflatoxin B1 in Common Carp, Cyprinus Carpio L. J Aquac Res Development 5: 240 doi:10.4172/2155-9546.1000240

33. Salem MFI, Shehab EI-Din MT, Khalafallah MMMA, Sayed SH, Amal SH (2010) Nutritional Attempts To Detoxify Aflatoxic Effects in Diets of Tilapia Fish (Oreochromis Niloticus). Journal of the Arabian Aquaculture Society. 5: 195206.

34. Abdelhamid AM, Khalil FFM, El-Barbary MI, Zaky VH, Husien HS (2002) Feeding Nile Tilapia on Biogen to Detoxify Aflatoxic Diets. Proc. 1st Ann Sc. Conf. Anim. \& Fish Prod Mansoura, Fac. Agric 24 \& 25 Sep. Pp 207-230.

35. Nguyen AT, Grizzle JM, Lovell RT, Manning BB, Rottinghaus, EG (2002) Growth and Hepatic Lesions of Nile Tilapia Oreochromis Niloticus Fed Diets Containing Aflatoxin $B_{1}$. Aquaculture 212: 311-319.

36. Kaneko JJ (1989) Clinical Chemistry of Domestic Animals, Academic Press, San Diego, Calif, USA, 4th Edition.

37. Boonyaratpalin M, Supamattaya K, Verakunpiriya V, Suprasert D, Hardy RW, et al. (2002) Effect of Aflatoxin B1 on Growth Performance, Blood Components, Immune Function and Histopathological Changes in Black Tiger Shrimp (Penaeus Monodon Fabricius). Aquacult Res 32: 388-398.
38. Caguan A G, Tayaban RH, Somga JR, Bartolome RM (2004) Effect of Aflatoxin Contaminated Feed in Nile Tilapia (Oreochromis Niloticus L.). In Proceeding of the $6^{\text {th }}$ International Symposium on Tilapia in Aquaculture (RB Remedios, GC Imir and K. Fitzsimons. Eds.) 172-178.

39. Joner A (2000) Mycotoxins.

40. Mohamed HM, Mokhbatly AA (1997) Pathologic and Immunologic Evaluation of Activated Charcoal in Treatment of Experimental Aflatoxicosis-B1 in Oreochromis Niloticus Egypt J Comp Path 10: 169-185.

41. Zaki MS (2012) Effect of Aflatoxin on Endocrine Status in Cat Fish (Clarius lazera). Life Sci J 9: 419-422.

42. Ruby DS, Masood A, Fatmi A (2013) Effect of Aflatoxin Contaminated Feed on Growth and Survival of Fish Labeo Rohita (Hamilton). Current World Environment 8: 479-482.

43. Robertsen B, Engstad RE, Jorgensen JB (1994) Beta-Glucans as Immunostimulants. In: Modulators of Fish Immune Response (Stolen J, 